\title{
Standing Still and Cutting in Line
}

The Culture of the Queue in India

\section{Ajay Gandhi}

\section{Q OpenEdition}

1 Journals

Electronic version

URL: http://journals.openedition.org/samaj/3519

DOI: 10.4000/samaj.3519

ISSN: 1960-6060

\section{Publisher}

Association pour la recherche sur l'Asie du Sud (ARAS)

\section{Electronic reference}

Ajay Gandhi, «Standing Still and Cutting in Line », South Asia Multidisciplinary Academic Journal [Online], Free-Standing Articles, Online since 15 March 2013, connection on 10 December 2020. URL : http:// journals.openedition.org/samaj/3519; DOI : https://doi.org/10.4000/samaj.3519

This text was automatically generated on 10 December 2020 .

\section{(c) (i) () $\Theta$}

This work is licensed under a Creative Commons Attribution-NonCommercial-NoDerivatives 4.0 International License. 


\title{
Standing Still and Cutting in Line
}

\author{
The Culture of the Queue in India
}

\section{Ajay Gandhi}

\section{Introduction}

1 Someone who visits Old Delhi may be elevated into the city from within. At the Chandni Chowk Metro station, passengers disembark onto a grey concrete platform awash with white light, and ride escalators upwards. ${ }^{1}$ As they drop their tokens and move towards the street exit, others prepare to descend down. The process is highly regimented. There is a queue at the ticket counter; there is a queue where the gate is opened; and there is a queue at security, as passengers are patted down, and their bags fed through a machine.

2 Passengers accept this serial queuing with good humour. Indeed, many find the exacting attitude to be exemplary. Arvind Kejriwal, a noted Delhi activist, comments:

If you travel by Indian Railways, you'll see chaos, confusion and corruption everywhere. But if you travel by Delhi Metro, you'll see everything in order. It is not because good people travel by Metro, it is because Metro has a right system in place' (Jeelani 2011: 25).

3 The railways are, in this view, a place of indifferent compliance and pell-mell arrangements. In contrast, the Metro is a paragon of public infrastructure because it safeguards rules and corrects aberrations.

4 This ethos is obvious as one enters a Metro station. A large board is divided into two categories: Do ('Stand in Queue') and Don't ('Jump over the Ticket Barrier'). Red electronic signs blink overhead: 'You are under CCTV surveillance, camera footage is recorded'. Private security guards, short, thin men in baggy uniforms, stand at entrances and exits. They are unarmed but ensure that an orderly flow is maintained; those who linger unduly, or are mystified by the exit process, are moved along. The guards are overseen by larger, uniformed men toting submachine guns. They are a combination of Delhi Police officers and Central Industrial Security Force (CISF) jawans. The CISF, a paramilitary force, guards key industrial and commercial sites in India. Their presence 
underlines the Metro's symbolic value: as a model of urban transport, of civic comportment, and of national arrival.

The Metro's militarized character obliges passengers to obey its strictures, foremost of the queue. Indeed, the local phrase, 'queue system', reveals how the queue is dependent on a system, and metonymic of that system. In other words, the queue comes into being through institutional authority; its functioning then serves as shorthand for that very authority. In this way, the Metro queue is an example of what Jean-Paul Sartre terms 'massification' (2004: 257). Whatever one's individual qualities are, a queue unifies or massifies them; an external authority subdues singular energies into a collective but passive form. The Metro queue is a form defined by 'prefabricated seriality': it is already there, waiting for newcomers to slot themselves into a linear format (Sartre 2004: 265).

Such a queue tells us how the state distributes political authority, enforces ideal behaviour, and imagines modern subjectivity (Corbridge 2004, Bogdanov 2012). This is not, however, the only way that queues are enacted, as one disgorged from Chandni Chowk's station will find. Past hand-carts stacked with fabric from an adjacent textile bazaar is a major thoroughfare. Next to a sweets shop, a small scrum of men stands before a bilingual sign: 'English liquor store'-angreezi sharab ki dhukan. A rusting iron grill demarcates the interior and exterior. Peering inside, a single light bulb illuminates a cramped space with two men and a boy propped up on brown boxes. Outside, government employees, market contractors and bus drivers jam their rupees into a small opening, shouting their orders. There is jostling and elbowing, and a tangled clot of limbs at the front; newcomers sidle up and arch their hands past others' faces. From time to time, a voice from within announces, 'stand in line, stand in line' (line mein khadde ho, line mein khadde ho). The tense clump relaxes, and a half-hearted attempt is made to self-arrange into a segmented entity; soon it deforms, and the earlier arrangement resumes.

Down the street is the Moti cinema, a single-screen theatre playing Bhojpuri and masala films. An interior courtyard plastered with posters-large collars and backless dresses abound-contains a ticket counter where people queue. Old Delhi's many mazdoorsunskilled labourers -crouch on their haunches; others, dressed simply but neatly in pants and tucked-in shirts, stand. They stand or squat faithfully, waiting their turn; others make different calculations. Women who enter the courtyard go straight to the front, bypassing the line. Other circumvent the queue entirely, and approach security guards sitting on plastic chairs. These men are armed with wooden lathis, but they are indifferent to queue discipline. Their main focus is on selling tickets, taken out of the ticket counter's official tally. For there is a quiet if public understanding: if a film is sold out, if a good seat is unavailable, or if the queue is too long, buy a 'black' ticket at an inflated price. This reflects how other queues operate, with an illicit but well-organized side arrangement. It may involve a 'broker' (dalal) or 'thug' (goonda), external to proper respectability but often emerging from, or closely allied to, the formal institution. Those in the queue can oscillate between different modalities simultaneously. The queuerespecting official-entry customer may also be the black-ticket procuring queue-breaker.

8 These are three types of queues in Old Delhi. The Metro's queue suggests, following Sartre, how institutional authority, such as that of the state, moulds public sociality into passive seriality. The queues at the liquor store and cinema demand another interpretation. Here, we benefit from Erving Goffman's insight that queues are a type of 'interaction order' or 'interaction arrangement' $(1971,1983)$. In such a milieu, norms are not simply externally enforced, but regenerated and renegotiated in each encounter. 
Queues are face-to-face activities organized around 'norms of co-mingling' (Goffman 1971: xi). For Goffman, this is an arena of 'presupposed competence', that is, norms generated via prior experience (1983: 14). In a queue, then, one's archive of previous experience, as well as fresh, contingent calibration, converge. Queuing does not simply imply formal obedience, but a wider array of 'patterned adaptations' which include 'conformances, by-passings, secret deviations, excusable infractions, flagrant violations, and the like' (Goffman1971: xii). The liquor store or cinema queue may seem chaotic or confusing, evidence of the breakdown of order. Yet we would do well, I will argue, to understand queue-jumping and line-circumventing not as moral or legal aberrations, but learned 'norms of co-mingling' and 'patterned adaptations'.

9 This paper provides an ethnographic assessment of queues in Delhi's old city, based on fieldwork conducted over 19 months between 2007 and 2009. I employ reflections of how queues are enforced, maintained and unfold, their common features as well as diverse iterations. In so doing, I group queues into two types so as to investigate two themes. First, employing Sartre, I examine 'massified' queues as expressions of state-subject relations in India. Queues can tell us much about the imagination of ideal modern conduct, and the mediation of elites to masses, in a postcolonial democratic polity. Second, utilizing Goffman's writings, the 'interactional' queue is viewed as the situational outcome of previously inculcated norms. Certain skills, obligations, entitlements, and investments converge to produce this ubiquitous type of public sociality. The queue thus reveals how people employ strategies to seek services and recognition.

In the following section, I define and discuss the variants of a queue. I identify it as a species of comportment, and show how its temporal and spatial features illuminate political and social life. In the succeeding two sections, I return to old Delhi and examine how various queues, in institutional and public settings, may be understood. First, I discuss queues that bear the heavy imprint of the state's institutional authority. Employing Jean-Paul Sartre's analysis, such 'massified' queues, I maintain, illuminate certain aspects of the state-subject relationship. The queue emerges as part of the Indian state's education of the mass body, as a technology for producing the modern subject. Sartre's analysis is useful to understand the normative investment in queues. It does not, however, provide insight into how they function from within. Therefore, in the succeeding section, I examine queues where institutional authority is absent or noncommittal, and internal dynamics are key. Basing this section on Erving Goffman's analysis, I argue that 'interactional' queues are not a technology for organizing bodies, but a situational relation of subjects to one another. Each person arrives in a queue based on an archive of prior engagements. But every subject is different, as is each line. Thus a queue is auto-generated and auto-enforced, each version exhibiting its own tics, idiosyncrasies, and patterned adaptations.

\section{What is a queue, and why should we study it?}

11 At its most elemental, a queue is the means by which access to service is regulated in time and space. Queues can be physical or virtual; the latter may include an organ transplantation, public housing, or private school waiting list. Virtual queuing also encompasses telephonic and digital traffic, where one waits alongside myriad invisible others. In India, virtual queuing defined certain features of the socialist period. In the 1980s, for example, the queue to procure a telephone connection or car was so long that 
these took years to obtain. Long waits to book and make trunk calls during this era were fittingly marked by the recorded message, 'aap katar mein hai; you are in queue'.

Physical and virtual queues share certain features, foremost that of real or imagined scarcity (Corbridge 2004: 190, Bogdanov 2012: 78). Queues exist because of an imbalance in the demand-supply equation. They are a response to the inability-or unwillingnessto provision a service to the extent desired. Further, both physical and virtual queues share an element of possible failure. Just as the sought-after service may or may not be available, queuing does not guarantee success. The ambiguity that surrounds scarcity, and the uncertainty of success, add much drama to queuing.

Physical and virtual queues not only share features; they often overlap (as when one physically lines up to receive a passport that was previously applied for, having passed through a bureaucratic conveyor belt). Despite this intimate relationship, this paper is concerned with physical queuing. Such queues have a privileged place in modern life: they are how one sends post, boards a train, cashes bank drafts, obtains match tickets, or attends the cinema.

The temporal dimension of queuing is evident as waiting; the spatial element, as linear sequencing. We may understand this time-space prescription as a species of comportment: as the Oxford English Dictionary defines it, one's bearing and behaviour. One comports to formal expectations, and one comports with others. Comportment implies involuntary adherence to prescribed rules, and voluntary agreement with existing practice. As the OED notes, comportment condenses bodily discipline, outward conduct and endurance of others.

The queue also makes us attentive to dimensions of linearity and universality. The queue could only have emerged in the modern age: aesthetically, it reveals a preoccupation with sequential segmentation to a defined end-point; politically, it signals rational, purposive and equitable-rather than impulsive, unplanned and prejudiced-access to services. As Tim Ingold notes, 'the straight line has become an icon of modernity. It offers reason, certainty, authority, a sense of direction' (2007: 167). To summarize the queue's defining features: it is a teleological and universal form; requires bodily self-containment; demands synchronicity with others; and inculcates a detached, disciplinary sense of space.

Having defined the queue, we may now ask: what is gained from its analysis? That answer is not obvious, for the study of Indian politics and sociality generally overlooks comportment. Scholars tend to privilege formal rules, visible signs, public discourse, or collective action. If politics and society are primarily found in texts, events, speech, and symbols, comportment becomes epiphenomenal. More recently, though, scholars of India have argued for greater attention to practices, dispositions, performances and styles. For example, Thomas Blom Hansen (2004) and Lisa Mitchell (2011) have shown how practices can illuminate ethnic assertion and political communication.

17 Compared to overt spectacles or dramatic practices, the queue, as a form of routinized comportment, may seem banal. However, I maintain that both as a consciously enforced outcome of state policy-that is, the queue as institutionally engineered ideal-and as an everyday, ingrained practice-the queue as the intersection of urban dispositions, and striations of class, gender and power-it reveals much about the distribution of entitlement and scarcity, and the validation of specific identities. 
18 For example, to return to the most elemental definition of the queue-involving the regulation of access to service in time and space-the experience of waiting, and the occupation of space, are significant. In eastern India, marginalized women and tribals may wait in queues, in the sun or rain, for hours or even days, to petition government officers (Corbridge 2004: 184). Political bosses and wealthier people, in contrast, walk straight in and demand an audience, signalling that 'waiting is something that poorer people do' (Corbridge 2004: 184). This is symptomatic of how Indian elites generally absent themselves of waiting's opportunity costs. It is not uncommon to find servants or drivers queuing at electricity board offices, paying the bills of their employers; similarly, superiors in an institutional hierarchy-such as police officers or executives-may send underlings to line up for event tickets. Such asymmetries in who is obliged, and who can evade queuing, reveal how social worth is distributed.

The queue's disciplining of bodies in space is also illuminating. It illustrates a polity's recognition of particular entitlements, and the instantiation of 'spatial etiquette' (Srivastava 2007: 185). In Indian banks, toilets, colleges, airports, and train stations, there is not just the queue, a single-file march to modernity. There are rather queues in the plural. In places of business and pleasure, one may see the following: a Priority Queue, a Ladies Queue, VIP Queue, Queue for Foreign Passport Holders, Queue for Gent's Toilet. As their titles suggest, accessing particular queues depends on recognized prerogatives and identities. Those lacking the requisite status or documents are explicitly excised from these lines. Such differentiated design accommodates the liberal notion of targeted assistance based on difference (Physically Handicapped Queue, Senior Citizens' Queue). It recognizes that certain groups may be inconvenienced or disadvantaged (Ladies Queue, Pensioners' Queue). Being intrinsic to the nation-state, it also valorizes certain convictions and sacrifices (Freedom Fighter Queue, Army Servicemen's Queue). In sum, the plurality of queues, and the policing of their entry, hints at political recognition and social entitlement.

Thus far, we have defined a queue, and located it as a variety of comportment. We have established how its temporal and spatial dimensions illuminate the distribution of power, rights, and privileges. Now we return, in the following two sections, to an ethnography of queues in Old Delhi. The first section is built off of Sartre's conceptualization of queues via institutional authority; the second section draws from Goffman's emphasis on the queue as a type of public sociality. In between these ethnographic vignettes, I thread in historic and contemporary examples of other Indian queues, so as to ground the argument in a wider milieu of politics and culture.

\section{Institutional authority and the 'massified' queue}

21 A hundred metres west of the Moti cinema sits Old Delhi's most prominent destination, a looming sandstone structure. It is the Lal Qila or Red Fort, built in the late $17^{\text {th }}$ century to house the Mughal emperor. Hundreds of people throng to it daily, mostly domestic visitors to the capital. There are plenty of queues: for tickets, for security, to enter the complex, and to enter museums within the fort.

22 At the ticket counter to the Red Fort, and in the security queue to enter it, official personnel stand. Because of the heavy traffic, a long line snakes along the wall, curling towards a green lawn. People in line cover their heads to guard against the sun, and 
clutch water bottles and cameras. Guards regulate the line when it becomes lumpy, holding bamboo sticks and periodically chastising people. Like the Metro, the monument is heavily securitized. There are police constables sitting in jeeps; army commandos whose guns poke out from sandbag embankments; and private guards who mill about the beeping, blinking security machine. Because of this, the queue retains a fairly coherent structure.

Now moving south-east, one may come across people gathered at a school next to the Meena Bazaar. During municipal and national elections, a polling booth is set up here, and local residents congregate to vote. As in the Metro and at the Red Fort, a queue forms, numbering, at its height, several hundred people who stream out of the school and into the adjoining bazaar. Those in line hold laminated identification cards, and documents verifying their address. Previous elections have been marred by voter intimidation, ballot tampering and 'booth-capturing' (when armed men attached to candidates stuff ballot boxes). Recent polls have therefore had a heavy police presence. This officiousness is supplemented by badge-wearing election commission observers who stand inside and outside.

The queue at the heritage monument is everyday, while the one during election polls is one-off. Both can be read via Sartre's text, the first volume of Critique of Dialectical Reason (2004). Sartre was a Marxist and existentialist. His understanding of the queue hinges on the ontological distinction between 'praxis' and 'inertia' (or the 'practico-inert'). For Sartre, inert social relations are found amidst conditions of 'seriality'. Here, subjects are passively ordered in time and space vis-à-vis an external authority.

An example of such inert seriality is the queue. Class, gender and age, notes Sartre, differentiate Parisians who queue for the bus at the Place Saint-Germain. Yet they are unified or 'massified' from the outside, a condition he sees as characteristic to metropolitan life (Sartre 2004: 256). Internal heterogeneity is trumped by structural homogeneity. An external institutional force constitutes the queue, and the subject within, a priori. Before each person arrives at the bus stop, the gathering that forms there 'already has a serial structure', and was 'produced in advance' by the bus stop's ticket machine; the queue is not a conscious, original structuring but 'already exists, and awaits him' (Sartre 2004: 265, original emphasis). Those who join a queue therefore consent to being slotted into a 'prefabricated seriality' (Sartre 2004: 265).

The individual features or essential qualities of those in the queue are irrelevant. The queue's 'massification' of social relations externally impinges, lumping each person into serial units (Sartre 2004: 257). A person is reduced to their mere interchangeability: 'each of them is effectively produced by the social ensemble as united with his neighbours, in so far as he is strictly identical with them' (Sartre 2004: 259). In this mode, each person adopts an 'attitude of semi-unawareness' of others, literally turning 'his back on his neighbour' (Sartre 2004: 259). The queue mandates, as it were, indifference to those proximate to oneself. In the queue, then, one is 'united by an abstract generality' and 'identical as separate individuals' (Sartre 2004: 260).

27 At one level, those queuing at Place Saint-Germain 'achieve practical and theoretical participation in common being' (Sartre 2004: 266). But this glue is mere shared selfinterest in service: 'acts of waiting are not a communal fact, but are lived separately as identical instances of the same act' (Sartre 2004: 262). Authentic camaraderie is displaced by an instrumental goal. For Sartre, a queue symbolizes a social order where one is alienated into a 'plurality of isolations' (2004: 256). The positive relations of reciprocity 
that define 'praxis' are absent. Instead, an existentially hollowed out state of 'inertia' is produced.

Sartre contrasts the queue with a non-alienating form: the French Revolution crowd threatened by the army (2004: 352-382). The crowd is egalitarian, and each individual actualizes their praxis towards collective fulfilment. Under siege and fused in common purpose, it exhibits an effervescence lacking in the collective but alienating queue. This contrast between the queue and crowd-and between 'praxis' and 'inertia'-echoes other thinkers who diagnose the modern condition by contrasting rational modulation and spontaneous communitas (Mazzarella 2009).

Sartre's thought experiment is insightful but limited. Let us examine what is of use, before we detail what falls short. Those who arrive at the Metro, the Red Fort and polling booth are also diverse in class, age and gender. In these milieus, they have little discretion in how they assemble. The state's overwhelming institutional presence indeed 'massifies' persons into a queue. Except in the rare instance of a political 'VIP', each individual follows the logic of 'prefabricated seriality'. The presence of guards, police, paramilitary and army personnel, and the symbolism of the venue and occasion, is important. These militate against any rupture to the queue's segmented, linear form; they induce a certain solemnity, a necessary passivity. To the authorities at these venues, each person's essence hardly matters. They are interchangeable with one another, notable only insofar as they have paid the entry fee, or are entitled to vote. Finally, the queue contains a 'plurality of isolations': one's ability to ride the Metro, enter the Red Fort, or cast a ballot, is contingent on their own cash or citizenship. These queues are comprised not of a community with intersecting agendas, but single actors oriented towards the same goal.

Sartre's take on the queue, when we widen our perspective, illuminates how the Indian state has conceived of, and sought to mould, its subjects. It is useful here to historicize how Indian authorities have viewed the masses, and then illustrate with examples of queue enforcement. Sartre, a Marxist of a specific vintage, found the crowd the very embodiment of praxis. Indian leaders and institutions have not shared this romance. This is unsurprising, for British colonizers saw crowds as dangerously anomic and subversive of order (Pandey 1992, Chandavarkar 1998).

Independence activists and nationalist reformers such as Mahatma Gandhi inherited this sensibility. Perhaps India's foremost ideologue of self-discipline, he termed a crowd's unruliness a 'mobocracy': 'Gandhi's own frustration was documented in the adjectives he used to describe the crowds: they were "unmanageable," "uncontrollable," "undisciplined"' (Guha 1997: 139). He bemoaned the masses' lack of 'sacrifice, discipline and self-control' (Guha 1997: 136); and 'the instances of noise and confusion, of boisterousness and meetings and breaking of ranks during marches...' (Guha 1997: 141). The public's inability to contain and channel their desires was manifest in their inability to do what queuing requires: be physically self-contained, synchronous with others, and obey an authority's orders.

32 To mostly futile effect, Gandhi 'formulated elaborate rules', and erected a 'disciplinary cordon' around crowds while travelling (Amin 1995: 168). Despite his injunctions about mass behaviour, the public often disappointed him. Such frustration was deeply felt. For nationalist reformers, proper comportment signalled a people's capacity to be modern and responsible. The 'rogues', 'rioters', 'mob' and 'criminals' who could not maintain decorum had to be expelled from official nationalism (Amin 1995: 46). 

independence in 1947. Indian commentators of civic virtue and modern reform repeatedly seize upon it. It most often becomes an indicator of insufficient development, deformed morals, and in-built callousness. Take a typical reflection on the lack of Indian 'civic sense' (Sharma 1990). The author finds public duty, collective responsibility, and respect for norms wanting:

We jump the queue without scruples, play truant in office, bend rules to suit our interests, and often fail to keep appointments. We care little for public norms of integrity and fair play. Instances of corruption, hypocrisy, favouritism, and other malpractices are not hard to find (Sharma 1990: 92).

an analysis of industrial proletarians, the authors are dismayed that 'in the mill, the workers, hardly observe decorum and discipline inside the canteen. Non-observance of Queue at the counter, washing hands in the plates after taking food, and resting legs on the dining tables are a common occurrence in the canteen' (Mohapatra et al. 1992: 68).

We have seen how historically, Indian authorities have been averse to crowds, and emphasized order. We have also recorded a persistent displeasure at the public's failure to queue. Numerous instances follow where the state enacted queues along 'massified' lines. Some examples will illustrate. Morarji Desai was among the many self-styled Gandhians in politics after independence. Home Minister of Bombay in the 1940s, he became Prime Minister in 1977. Desai's autobiography enumerates his work as Home Minister in 'disciplining the masses' (Hardiman 2003: 31). He censored films, and violently suppressed communist-led movements. Among these achievements, "he forced commuters to stand in orderly queues at bus stops, even posting police to create the correct atmosphere of "discipline"' (Hardiman 2003: 31).

This demand to queue properly, as an expression of citizenly competence, has continued since. In the 1990s, the municipal government in Delhi responded to dangerous bus accidents. Such incidents were blamed on passengers jostling and elbowing as they entered or exited. Once again, the state finds the unorganized and non-sequential crowd at fault, leading to injuries and fatalities. Delhi Police guidelines for school children contrast the ideal queue against the unruly mob: 'At the bus stand, always follow the queue. Board the bus only after it has come to a halt, without rushing in or pushing others. While in the bus, shouting or making a noise is definitely bad manners. Such behaviour can also distract the driver' (Sundaram 2009: 198). This normative effort to shape comportment is echoed by the economist Kaushik Basu, recalling a Kolkata initiative that trained people to queue for buses. His language, like that of the Delhi Police, contrasts the positive queue and negative crowd: 'there were volunteers with loudspeakers, urging anarchic gatherings of men and women at bus stops to "stand in a line"' (Basu 2004).

The key term invoked in these examples is discipline: the masses are seen to be unable or unwilling to adopt it. The crowd is understood as pre-rational and overly passionate. Queue jumping is equated with indiscipline. For technocrats and planners, the prefabricated, serial queue moulded by external authority becomes an ideal. It is upheld as the fleeting sign of rational modernity. The 1970s Emergency, when the government suspended democratic institutions, is revealing in this regard. This period can be considered a technocratic experiment in hardwiring public discipline. State slogans displayed in public spaces reiterated the point: 'Discipline Makes the Nation Great' (Guha

South Asia Multidisciplinary Academic Journal , Free-Standing Articles 
2007: 494). Sanjay Gandhi, son of the Prime Minister, and proponent of the Emergency, judged it as follows: 'the greatest gain is a sense of discipline and the speeding up of work... what has the country lost? Smuggling, black-marketing, hoarding, bus burning and the habit of coming late to work' (Guha 2007: 510).

Bureaucrats utilized their greater powers to fast-track urban beautification and population control. These were often conducted under coercive circumstances. Vulnerable individuals were obliged to undergo sterilization so as to receive housing or promotions (Tarlo 2003). Despite such strictures, the state fetishized ostensibly voluntary participation. Public Information Bureau images of this time show calm queues of men waiting to undergo vasectomies (Tarlo 2003: 64-65). The queue thus implies citizenly consent and passive obedience. An organizer of a vasectomy camp recollects its success in 'overcoming the resistance' of the public's 'embarrassment' and 'prudery': 'The prospective acceptors could be seen standing in queue in front of the operation room as casually and without any self-consciousness as if they were at the ticket-counter of a cinema hall' (Devika 2005: 364). To state authorities and allied elites, the Emergency queue signals a desired transformation in the masses. Yet the orderly, serial, passive queue has only come about via institutional authority. It thus represents a notion of mass reform that hinges on political coercion, not internal reason.

In this way, the queue's invocation echoes Lawrence Cohen's argument, drawing on the Emergency vasectomy of India's 'as-if' modernity (2004). His argument is that bureaucratic elites reproduce a colonial notion of 'the masses' with passion but not reason; that development is organized around a transformation of reason in a population it constitutes as radically disjunct from reason itself; that the operation becomes a means by which the state can reimagine its conditions of possibility given this contradiction. Thus 'sterilization produces a body that performs as if it had undergone a transformation of reason, as if it were inhabited by an ascetic will' (Cohen 2004: 166, original emphasis).

Let us briefly summarize this section. We have examined queues in Old Delhi that closely approximate Jean-Paul Sartre's theory. At the Red Fort and polling station, we found a heavy institutional presence that results in a 'massified' queue, one that embodies 'prefabricated seriality', and where people seem a 'plurality of isolations'. We have also delved into related historical and contemporary examples of queues, finding a similar emphasis, deriving from longstanding norms, on order and discipline. That the queue has so often been instantiated by institutional authority provides insight into the state's imagination of the masses. This is most obviously crystallized in the example of the Emergency queue for sterilization. Such a queue suggests both an official desire for proper, self-generated comportment, and a disbelief that such behaviour can be generated in the absence of securitized pressure.

41 Having extracted Sartre's insights, we may now discuss his theory's weaknesses. Sartre repeatedly emphasizes the queue as an example of externally imposed order, of the 'massification' of capitalist, urban society. This idea of a form that institutionally and externally impinges is important. Yet we are bereft in reading other types of queues that disrupt or upend this modular aspect. For example, it is not uncommon for someone in a queue to plead to others that they be allowed cut in line; in some cases, they don't even ask. That queue-jumping or line cutting is frequently allowed, by both those in the queue as well as external authorities (security guards and service providers) suggests a more complex form than that set out by Sartre. The creation of a homogenous form or interchangeable subjects is thus a tentative and incomplete accomplishment. These exist 
in tension with patterned adaptations, with emotional appeals, that complicate the queue's seeming rigidity.

Another line of critique extends to Sartre's assumption that the queue is not a 'communal fact', but a kind of 'prefabricated seriality' leading to a 'plurality of isolations'. The queue, a monotonous emblem of individualized capitalism, finds its foil in Sartre's revolutionary crowd. Yet if the analysis stops here, we cannot explain how queues sometimes serve as an instantiation of collective energies.

This can be illustrated through another example of election queues. In a study of the 2009 national elections, Mukulika Banerjee notes the mood at polling booths: 'the atmosphere was solemn, as people formed separate and orderly queues for men and women, waiting patiently even when they were long' (2012: 89). Thus far, it resembles the 'massified' queues we have examined in this section. Banerjee notes that people of different castes, normally not present in the same space, 'commented on this forced social mingling with a mixture of disbelief and grudging admiration at what a radical alteration a simple election queue could achieve, forcing even supporters from rival parties to stand cheek by jowl' (2012: 89). She concludes, 'the queue's liminality facilitates direct unmediated communication between individuals free of social structure and generates a rare egalitarianism in society at large'.

In other words, while the election queue is highly segmented and serial, in line with Sartre's theory, it can also flatten hierarchies. In a society with deep asymmetries, the queue can be a time-space nexus where difference is momentarily levelled. When queues are attached to collective forms of paying fealty and giving regards, they can encompass as much as they parse. ${ }^{2}$ This suggests that we need to bracket aside institutionally engineered queues, and examine how they internally unfold. To do this, we will in the next section study 'interactional' queues in Old Delhi.

\section{The 'interactional' queue}

During the time I conducted my fieldwork in Old Delhi, I periodically made trips to Punjab, Rajasthan and Uttar Pradesh. I could purchase tickets for long-distance trains at the Delhi Junction station, located next to the Chandni Chowk Metro. I came to know the station well, and spent many hours in the ticket queue.

During these hours, I tried to decipher what was happening around me. The room for tickets was sparse, with hand-painted timetables on the wall, and booking forms scattered in the back. Fans caked with black grime spun very slowly overhead, and the wall paint was peeling and flaking. No security guards were present. The room was divided into different lines. The General Queue, where I was planted, was the longest and slowest. It was overwhelmingly male, and, during busy periods, a scene of involuntary bodily intimacy. The compressed distance between those behind and ahead precluded Sartre's 'attitude of semi-unawareness'. People often opened up conversations with others in the queue. Men who were illiterate asked for help filling in forms. Some stared unabashedly, scrutinizing the clothing and accessories of others. If someone had finished reading a newspaper, another might ask to borrow it. When a person was playing a song on their mobile phone, others would hum along.

The atmosphere in the queue could become tense, especially when it was warm, and the railway staff took tea breaks. Imagine a room filled with several dozen customers, wilting 
in the heat. At the appointed tea break time, the staff abandon their seats and put stiff cardboard at the ticket window. Behind a transparent Lucite counter, those in the queue can see an air-conditioned room with clerks, drinking tea and eating biscuits. Such a moment is bound to raise tempers, and as the break wore on, some would yell at the staff who chatted amiably inside, apparently oblivious to the waiting horde. Others sighed, made jokes, sat and played cards. The queue was at once a scene of patience, frustration, resignation and lightness.

The other inducement to tension was when people tried to cut into line. This was a not infrequent occurrence, and could unfold in a more or less subtle manner. The lines marked for the General Queue became, towards the ticket counter, less and less distinct. The blurriness between one queue and another created opportunities. Some simply walked in between different queues and parked themselves next to the ticket counter. Others tried to nonchalantly stand somewhere between the front and the middle. They clearly hoped to become subsumed by the line, as if by osmosis. Then there were those who asked if they could join you at your place in the queue, usually making a plea about how urgent their travels were. These strategies were never entirely predictable, and neither were the responses. Someone who had inelegantly butted into line could be collectively accosted: 'Why are you breaking the line?' (queue kyun tod rahe ho?). Queuejumpers opened themselves to men's insults: 'Bastard, go back and get in the line from there' (harami, udhar jao). Violators were taunted in terms of deficient morals: 'Don't you have any manners?' (koi tameez nahin hai?). Such ripostes illustrated how the queue was understood through a moral vocabulary.

Two other features of the room were striking. The first was how the Ladies Queue operated. This line existed so women could avoid proximity to men in the General Queue, and pre-empt groping and sexual harassment. The Ladies Queue was therefore shorter. Customers sought to take advantage of this. Some families would enter the room, women going to the queue and the men huddling in the back, filling in a form. The woman's turn would come. Since they had not filled in the booking form, the men would materialize by their side, and complete the transaction. Despite the large words painted overhead, 'For Ladies Only', the queue was strategically hijacked.

Another way of gaming the queue presented itself with the tout. They were usually young men who stood at the entrance and approached people filling in forms. They were often understood to be unsavoury but necessary. Hindi signs warned: 'Do not buy reserved tickets from unauthorized people. Do not contact brokers to buy tickets' (Anadhikrat vyakti se ticket arakshit ticket naa kharidein. Ticket kharidne ke liye dalalon se sampark naa karein). The tout functioned like the 'broker' or dalal, short-circuiting the established method for a fee. ${ }^{3}$ If you didn't want to queue, they stood in line and purchased tickets at the counter. When tickets for a particular train were overbooked, touts had connections with railway officers working in the back. Such touts worked their connections with staff to procure tickets for unfilled seats reserved under a special quota. By doing so, a customer could get a seat on an otherwise sold-out train as a 'freedom-fighter' or 'sportsman'. The language between tout and customer conceded that such queue circumvention was morally murky. A tout might offer to get a ticket 'on the black market' (black se); or by 'going out back and getting it done' (piche se karwa doonga). That said, customers didn't mind the touts' presence, and I saw people conferring with them before deciding to stand in line. The tout represented a clever strategy, rather than an 
unsavoury practice. In other words, rather than being seen as an illegitimate threat to order, the tout represented a valid method of obtaining service.

How do we decode the culture of the queue at Delhi Junction station? Sartre's theory is unable to fully impart a sense of its various dynamics. This queue is not a sterile space of robotic passivity, but intensely active. Notions of communal fairness and justice combine with micro-strategic and self-interested behaviour. This is where we may benefit from Erving Goffman's understanding of the queue within the 'face-to-face domain' he termed the 'interaction order' (1983: 2). Rather than treating it 'as "effects", that is, as indicators, expressions or symptoms of social structures' (Goffman1983: 2), Goffman maintains that it unfolds through its own situational and circumscribed rules. Queues are among the faceto-face activities organized around defined by certain 'norms of co-mingling' (Goffman 1971: xi). In a crucial difference from Sartre's reading, Goffman maintains that such norms are not simply enforced by external authorities, but regenerated and renegotiated in each encounter.

For Goffman, such face-to-face interaction in public is defined by 'personal territoriality' (1983: 4), and the need to manage territorial claims. ${ }^{4}$ Partly this involves the script people carry into public situations, 'an already established biography of prior dealings' (1983: 4) and 'presupposed competence' (Goffman 1983: 14). Because of this, those in the queue utilize 'emotion, mood, cognition, bodily orientation, and muscular effort', and display 'ease and uneasiness, unselfconsciousness and wariness' (Goffman 1983: 3). Such sociality involves scanning others, reading intent, and readjusting expectations. 'Presupposed competence' implies awareness of correct procedure. But those in the queue also utilize a broader array of 'patterned adaptations' such as 'conformances, by-passings, secret deviations, excusable infractions, flagrant violations, and the like' (Goffman 1971: xii). As Goffman notes, 'interaction arrangements can withstand systemic violation, at least over the short run' (1983: 5).

53 For Goffman, a queue cannot be evaluated on objective or universal criteria: 'what is desirable order from the perspective of some can be sensed as exclusion and repression from the point of view of others' (1983: 5). Further, 'it is not uncommon that individuals seeking service feel (whether justified or not) that they have been given unequal and discourteous treatment' (Goffman 1983: 15). A moral understanding suffuses the queue, underwritten by the understanding that 'all candidates for service will be treated "the same" or "equally," none being favoured or disfavoured over the others' (Goffman 1983: 14). The queue 'produces a temporal ordering that totally blocks the influence of such differential social statuses and relationships as the candidates bring with them to the service situation' (Goffman 1983:14). Most obviously, 'the turn', such as the principle of 'first come, first served', establishes an entitlement in the form of a territorial claim (Goffman 1971: 36).

This principle of equality is in tension, Goffman maintains, with other factors. While those arriving in a queue carry a script of its sequential and equitable nature, they also employ certain assumptions about qualification for service. For example, 'situationally perceptible qualifications regarding age, sobriety, language ability, and solvency will have to be satisfied' (Goffman 1983: 15). Thus, the 'relaxation of queuing constraints' may follow those who 'plead or display extenuating circumstances, beg to be allowed precedence' (Goffman 1983: 15). active strategizing, as one holds one's place, responds to others, and wards off 
interlopers. Physical stamina and emotional investment are both required. A sense of unfairness and of having received 'discourteous treatment' is evident in how customers react to the clerks' tea break. On the one hand, the principle of 'personal territoriality' and 'the turn' is upheld; queue-jumpers may be shouted at and forced to retreat. In this sense, the queue embodies values of equality and justice. At the same time, these principles can be suspended; 'relaxation of queuing constraints' is evident when men join women in the Ladies Queue, and when line-breakers are allowed entry into the General Queue, pleading 'extenuating circumstances'. With the practice of obtaining tickets through touts, we see the full range of 'patterned adaptations', involving 'secret deviations, excusable infractions, flagrant violations'.

Goffman's theory of the queue allows us to see it as a microcosm of norms and strategies being worked out. Every queue that regulates access to service in time and space, in this view, invokes justice and equality. But there is no such thing as the perfect queue; such comportment is always renegotiated, the principles underlying them under various forms of assault. We may consider this to be a pervasive if irresolvable tension in a democratic society. There is widespread investment in a just, equitable form of access to scarce resources. But there is an equally widespread interest in circumventing or foreshortening this burden.

Examples from elsewhere in India help to illustrate this point. The following demonstrates fidelity to the idea of the queue, as well as 'patterned adaptations' that undermine it. Let us start with a wry example from a book by the journalist Geoff Dyer, based on his time in Benares (2009). In one scene, the protagonist queues at an automatic teller machine, seeking to withdraw rupees. He soon becomes agitated when a couple ease into line ahead of him. He starts to lecture the man about his callousness, but the man neither protests nor admits fault. The queue-jumper persists, silently but aggressively, and the protagonist reflects: 'My rival was not interested in the etiquette or principle of queuing. He simply wanted to use the bank machine quickly. That was that. Whereas for me, my place in this queue-indeed the continued existence of the very idea and principle of the queue-was at stake' (Dyer 2009: 227). The protagonist acknowledges the curiosity of such a queue, a form both upheld and undermined: 'Strictly speaking, it was not a queue at all; at the same time it was not not a queue... a sort of queue in which the principle of the queue was neither completely ignored nor adhered to' (Dyer 2009: 227, original emphasis).

This passage finds resonance in ethnographic and journalistic accounts. In the mid-1970s, a journalist in Delhi noted:

There isn't anyone, rich or poor, who is not obliged to queue for something... Mailing a letter may involve several queues: one for getting the letter weighed, another for buying a stamp, a third for having the stamp cancelled before one's eyes, so that it will not be used by the postal clerk to help buy a meal. Even so, there is no guarantee that the letter will ever reach its destination. The people in the queues visibly seethe with impatience, anger, and hatred, and many a brawl breaks out, even though the police are often posted to keep order' (Mehta 1974: 155-156).

In a south Indian city, an anthropologist finds that cinema fans 'may arrive hours early, and sit or squat in queues, chewing betel, eating snacks talking with people nearby... when the booths open about one-half hour prior to showtime, the neat, patient queues become a crush of people pushing past one another in the narrow aisle' (Dickey 1993: 39). 
60 are negotiated in each queue. To line up in a segmented, serial manner does not preclude other strategies, such as pushing or tussling. Such comportment reveals the irresolvable tensions in society-even, or perhaps especially, when anger and impatience are manifest in the queue. In this sense, there is nothing peculiarly Indian about such queue conduct. In Russia, queues are rife with 'arguments, squabbled, and verbal wrangling over who's right and who's wrong' (Bogdanov 2012: 85). In Brazil, conflict over wealthier and whiter people jumping the queue illustrates how performances of citizenship 'require the negotiation of powers, rights, and vulnerabilities' (Holston 2007: 15).

61

I would like to suggest that this somewhat tumultuous survey of queuing invites us to more creatively examine comportment. In Partha Chatterjee's influential formulation, India is divided into two realms (2004). The bourgeois ideals of modernity and rational deliberation are embodied in 'civil society'. This comprises 'a small section of culturally equipped citizens' who 'occupy the high ground of modernity' (Chatterjee 2004: 111). The ragged field of political contestation is termed 'political society'. There is thus an 'inescapable conflict between the enlightened desires of civil society and the messy, contentious, and often unpalatable concerns of political society' (Chatterjee 2004: 77)

To demarcate an entire swath of public conduct as defined by the 'enlightened desires' of 'culturally equipped citizens' seems counter to evidence. For example, public comportment may exemplify a moral commitment to equality and justice, a sensibility put into tension by attempts to co-opt or intimidate. This is, I think, not a 'messy' or 'unpalatable' sensibility, but exactly how democracy works: the constant recalibration of what is appropriate in the banal interstices of life with anonymous others. What India's public comportment does not suggest, however, is genteel civility. Ironically, those who are most impatient and most unlikely to tolerate scarcity are the very elite that Chatterjee terms 'civil society'.

63 A journalist reports how elites are prone to become agitated when they cannot circumvent long queues:

Upper-class Indians, used to be waited upon by an army of servants, are much more impatient than even Americans when held up. A slight glitch at security check or a flight delay has them grumbling and groaning, wiping their brows and calling for the manager. A longer-than-usual queue brings out their frustrations with India's weak infrastructure in particular and governance in general' (Maheshwari 2012: 45).

Another journalist reports how Mumbai's voter turnout has dropped:

A series of text-message jokes imagine the excuses given by Mumbai's elite for not voting: 'No valet parking at polling booth' is one; 'spotted servant in queue ahead of us' another (Gentleman 2009).

If members of 'civil society' are so unwilling to compromise personal convenience, and so disdainful of other classes, that they find queuing intolerable, we need to rethink the usefulness of our analytical categories. 


\section{Conclusion}

This paper has employed reflections of how queues are enforced, maintained and unfold in old Delhi. I first discussed queues as a species of comportment, and showed how as a recurrent temporal and spatial practice, they illuminate the distribution of power, rights, and privileges. Then, employing Jean-Paul Sartre, I provided examples of 'massified' queues produced through institutional authority. These lines are visible in Delhi's Metro, at the Red Fort, and during election polls. Such forms tell us much about the state's ideal of modern conduct. Queues emerge as a technology for mass education, and are the embodiment of democratic access to services. Thereafter, utilizing Erving Goffman's writings, I surveyed the 'interactional' queue. Such lines are manifest in Delhi's liquor stores, cinemas, and train stations. This type of line is the situational outcome of previously inculcated norms and auto-generated adaptations. Varied skills, obligations, entitlements, and investments converge as people strategically manoeuvre for services. By offering a fine-grained description of the stakes involved in queuing, the paper has sought to illuminate political norms and public conduct in a postcolonial democratic milieu.

\section{BIBLIOGRAPHY}

Amin, Shahid (1995) Event, Metaphor, Memory: Chauri Chaura 1922-1992, Berkeley: University of California Press.

Banerjee, Mukulika (2012) 'Elections as Communitas', in Arjun Appadurai \& Arien Mack (eds.), India's World: The Politics of Creativity in a Globalized Society, Delhi: Rain Tree, pp. 71-92.

Basu, Kaushik (2004) ‘Queues and Capitalism', URL: http://news.bbc.co.uk

Bogdanov, Konstantin (2012) ‘The Queue as Narrative: A Soviet Case Study', in Albert Baiburin, Catriona Kelly \& Nikolai Vakhtin (eds.), Russian Cultural Anthropology after the Collapse of Communism. Oxford: Routledge, pp. 77-102.

Chandavarkar, Rajnarayan (1998) Imperial Power and Popular Politics: Class Resistance and the State in India, C. 1850-1950, Cambridge: Cambridge University Press.

Chatterjee, Partha (2004) The Politics of the Governed: Reflections on Popular Politics in Most of the World, New York: Columbia University Press.

Cohen, Lawrence (2004) 'Operability: Surgery at the Margin of the State', in Veena Das \& Deborah Poole (eds.), Anthropology in the Margins of the State. Santa Fe: School of American Research Press, pp. 165-90.

Corbridge, Stuart (2004) 'Waiting in Line, or the Moral and Material Geographies of QueueJumping', in Roger Lee and David Smith (eds.), Geographies and Moralities, Oxford: Blackwell Publishing Ltd, pp. 183-98. 
Devika, J. (2005) 'The Malayali Sexual Revolution: Sex, "Liberation” and Family Planning in Kerala', Contributions to Indian Sociology, 39 (3), pp. 343-74.

Dickey, Sara (1993) Cinema and the Urban Poor in Urban India, Cambridge: Cambridge University Press.

Dyer, Geoff (2009) Jeff in Venice, Death in Varanasi, New York: Canongate.

Gentleman, Amelia (2009) 'Indian Elections: Satire Campaign Aims to Bring out Youth Vote', The Guardian, 11 May.

Goffman, Erving (1971) Relations in Public: Microstudies of the Public Order, London: Allen Lane.

Goffman, Erving (1983) ‘The Interaction Order', American Sociological Review, 48, pp. 1-17.

Guha, Ranajit (1997) Dominance without Hegemony: History and Power in Colonial India, Cambridge: Harvard University Press.

Guha, Ramachandra (2007) India after Gandhi: The History of the World's Largest Democracy, New York: Harper Collins.

Hall, Edward (1963) 'Proxemics-the Study of Man's Spatial Relations and Boundaries', American Anthropologist, 65, pp. 1003-26.

Hansen, Thomas Blom (2004) 'Politics as Permanent Performance: The Production of Political Authority in the Locality', in John Zavos, Andrew Wyatt \& Vernon Hewitt (eds.), The Politics of Cultural Mobilisation in India, New Delhi: Oxford University Press, pp. 19-36.

Hardiman, David (2003) Gandhi in His Time and Ours: The Global Legacy of His Ideas, London: Hurst \& Co.

Holston, James (2007) Insurgent Citizenship: Disjunctions of Democracy and Modernity in Brazil, Princeton: Princeton University Press.

Ingold, Tim (2007) Lines: A Brief History, Oxford: Routledge.

Jeelani, Mehboob (2011) 'The Insurgent', The Caravan, September, pp. 22-35.

Maheswari, Vijai (2012) ‘The Culture of Queuing’, Open Magazine, 13 August, pp. 44-45.

Mazzarella, William (2009) 'Affect: What Is Is Good For?, in Saurabh Dube (ed.), Enchantments of Modernity: Empire, Nation, Globalization. London: Routledge, pp. 291-309.

Mehta, Ved (1974) 'Letter from New Delhi', The New Yorker, pp. 147-61.

Mitchell, Lisa (2011) “"To Stop Train Pull Chain”: Writing Histories of Contemporary Political Practice', The Indian Economic and Social History Review, 48 (4), pp. 469-95.

Mohapatra, A.K., D.V. Giri, and B.S. Murthy (1992) Industrial Indiscipline in India, Delhi: Ashish Publishing House.

Pandey, Gyanendra (1992) The Construction of Communalism in Colonial North India, Delhi: Oxford University Press.

Parry, Jonathan (2000) 'The "Crisis of Corruption" and "the Idea of India”: A Worm's Eye View', in Italo Pardo (ed.), Morals of Legitimacy: Between Agency and System, New York: Berghahn, pp. 27-55.

Sartre, Jean-Paul (2004 [1960]) Critique of Dialection Reason Volume 1, Translated by Alan Sheridan Smith. London: Verso.

Sharma, S. L. (1990) 'Institutional Structures and Social Systems', in Jurgen Azer (ed.), Citizenship Values in India: Individualism and Social Imperatives, Calcutta: Popular Prakashan, pp. 87-96. 
Srivastava, Sanjay (2007) Passionate Modernity: Sexuality, Class, and Consumption in India, Delhi: Routledge.

Sundaram, Ravi (2010) Pirate Modernity: Delhi's Media Urbanism, London: Routledge.

Tarlo, Emma (2003) Unsettling Memories: Narratives of the Emergency in Delhi, London: Hurst \& Company.

\section{NOTES}

1. I am grateful to Kushanava Choudhury, Nicolas Jaoul, Christine Moliner, Olga Sooudi and Samaj's two anonymous reviewers for their suggestions.

2. Queues may unify along lines of loyalty or conviction, while simultaneously demarcating and dividing. This is evident during ceremonial or ritual occasions. During national holidays or commemorative occasions, Indian civic groups and political parties often organize functions. As part of the festivities, activists or adherents will stand in a long queue to garland a statue, or genuflect to a noteworthy figure. Here, those in the queue are united as part of a select community, distinct from those outside of it. This is also evident in large temples, such as Tirupati in Andhra Pradesh, and the Sai Baba temple in Shirdi, Maharashtra. Both attract thousands of visitors daily. In both, temple authorities set up general queues, which are free but involve a long wait. Shorter express queues are also available to politicians, donors, and those willing to pay. On the one hand, the community of devotees is united by shared presence. At the same time, separate queues isolate aspirants by income and status.

3. For related examples of dalals facilitating clients' access to the queue, or circumventing it through their influence with authorities, see Parry (2000) and Corbridge (2004).

4. The tacit rules governing the queue are usefully encapsulated in Edward Hall's term 'proxemics', or the perception, use, and structuring of space. Proxemics concerns how a person 'unconsciously structures microspace', including 'the distance between men in the conduct of daily transactions' (Hall 1963: 1003). For Hall, proxemics mainly concerns a subject's claim over territory. Yet this most basic assertion, he maintains, is guided by norms that are not explicitly articulated, and exist on different 'levels of awareness' (Hall 1963: 1003). A focus on proxemics underlines the importance of sensorial factors-voice modulation, smell, sight, and touch-in governing how people maintain or violate rules of distance. Queue culture is suffused by generally unarticulated, but widely understood proxemic rules.

\section{ABSTRACTS}

The queue, or the line, is a defining feature of modern life. This paper examines this ubiquitous form in India as a species of comportment. It offers an ethnographic assessment of queues in Delhi. They are grouped into two types: the 'massified' queue, drawing on Jean-Paul Sartre's work; and the 'interactional' queue, framed by Erving Goffman's writings. The paper discusses heavily policed queues, whose linear and serial character is produced by institutional authority. These forms suggest that elites engineer such comportment as a sign of rational distribution and civic order. The paper then illustrates the interactional dynamics of queues from within. Queues 
are shown to be sites of subtle signalling, where social entitlements are contextually processed. The queue's enforcement via external authority is thus leavened by auto-generated adaptations. By offering a fine-grained description of how queuing unfolds, the paper seeks to illuminate political norms and public conduct in a postcolonial democratic milieu.

INDEX

Keywords: queue, lines, comportment, discipline, public sociality, India

\section{AUTHOR}

AJAY GANDHI

a Postdoctoral Research Fellow at the Max Planck Institute for the Study of Religious and Ethnic Diversity in Göttingen, Germany 